\title{
HUBUNGAN ANTARA STATUS ANEMIA, TINGKAT AKTIVITAS FISIK, KEBIASAAN SARAPAN, DAN DEPRESI PADA REMAJA PUTRI DI KOTA YOGYAKARTA
}

\section{Relationship between Anemia Status, Physical Activity Level, Breakfast Habit, and Depression among Adolescent Girls in Yogyakarta City}

\author{
Restu Amalia Hermanto ${ }^{1 *}$, BJ Istiti Kandarina ${ }^{2}$, Leny Latifah ${ }^{3}$ \\ ${ }^{1}$ Program Studi IImu Gizi STIKes Holistik Purwakarta \\ Jl. Veteran No. 272 Purwakarta, Jawa Barat, Indonesia \\ 2Departemen Biostatistik, Epidemiologi dan Kesehatan Populasi, Program Studi Ilmu Kesehatan \\ Masyarakat, Fakultas Kedokteran, Kesehatan Masyarakat, dan Keperawatan, Universitas Gadjah Mada \\ Jl. Farmako, Sekip Utara, Depok, Sleman, Yogyakarta, Indonesia \\ ${ }^{3}$ Balai Penelitian dan Pengembangan Kesehatan Magelang \\ Kapling Jayan, Borobudur, Magelang, Jawa Tengah, Indonesia \\ *e-mail: restuamalia@stikesholistic.ac.id
}

Submitted: November $3^{\text {rd }}$, 2017, revised: October 25th 2019, approved: November $24^{\text {th }}, 2019$

\begin{abstract}
Background. Depression in adolescent was the cause of the burden of disease, losses of productivity, and increasing the risk of metabolic syndrome in adulthood. Prevalence of mental health disorder aged 15-24 years in Yogyakarta Province was 9.5 percent. Iron has an important role in the formation of emotional behavior because of its role as a cofactor of serotonin and dopamine synthesis in the brain. In addition, the level of physical activity and diet pattern also contribute to maintaining the balance of the neurotransmitter. Iron deficiency is a major factor that cause anemia among adolescent girls. Prevalence of anemia among female adolescents in Yogyakarta reached 35.2 percent in 2012. Objective. This study aimed to evaluate the relationship between anemia status, physical activity level, breakfast habit, and depression among female adolescents in Yogyakarta. Method. Cross-sectional study with 250 high school students aged 14-18 years in Yogyakarta. Adolescent depression was measured using Adolescent Depression Inventory and hemoglobin concentration to determine anemia status. Bivariate data analysis using chi square. Results. There was no significant relationship between anemia $(R P=1.7 ; C l=0.969-3.034 ; p>0.05)$, lower levels of physical activity $(R P=0.9 ; C l=0.461-1.809$; $p>0.05)$ with the incidence of depression in adolescent girls in Yogyakarta. Nutrient intake of iron also showed no significant relation with depressive incident $(p>0.05)$. However there was a relationship between breakfast habits and depression among adolescent girls $(R P=1,52 ; \mathrm{Cl}=$ 1,071-2,162; $p<0.05)$.Conclusion. Breakfast habits can be associated with the incidence of depression among adolescent girls. Although the proportion of adolescent depression was quite high in this study, it association with anemia has not been demonstrated significantly.
\end{abstract}

Keywords: anemia, breakfast habit, depression, female adolescents, physical activity

ABSTRAK
Latar Belakang. Depresi pada remaja merupakan pencetus beban penyakit, mengakibatkan
kerugian karena kehilangan produktivitas, dan meningkatkan risiko sindrom metabolik saat
dewasa. Gangguan mental emosional pada kelompok usia $15-24$ tahun di Daerah Istimewa
Yogyakarta (DIY) sebesar 9,5 persen. Zat besi mempunyai peran penting dalam pembentukan
perilaku emosional karena perannya sebagai kofaktor sintesis serotonin dan dopamin otak.
Selain itu, tingkat aktivitas fisik dan pola makan (kebiasaan sarapan) berkontribusi juga dalam
menjaga keseimbangan neurotransmiter tersebut. Defisiensi zat besi merupakan faktor utama
penyebab anemia pada remaja putri. Prevalensi anemia remaja putri di Kota Yogyakarta 
mencapai 35,2 persen pada tahun 2012. Tujuan. Penelitian ini bertujuan untuk mengetahui hubungan status anemia, tingkat aktivitas fisik, kebiasaan sarapan, dan depresi pada remaja putri di Kota Yogyakarta. Metode. Penelitian dilakukan dengan desain cross sectional. Subjek penelitian adalah 250 remaja putri SMA usia 14-18 tahun di Kota Yoyakarta. Depresi remaja diukur menggunakan Inventori Depresi Remaja (IDR) dan kadar hemoglobin untuk menentukan status anemia. Analisis data bivariat menggunakan chi square. Hasil. Ada hubungan antara kebiasaan sarapan dengan depresi pada remaja putri $(\mathrm{RP}=1,52 ; \mathrm{Cl}=1,071-2,162 ; p<0,05)$. Tidak terdapat hubungan yang signifikan antara anemia $(\mathrm{RP}=1,7 ; \mathrm{Cl}=0,969-3,034 ; p>0,05)$, tingkat aktivitas fisik rendah $(\mathrm{RP}=0,9 ; \mathrm{Cl}=0,461-1,809 ; p>0,05)$ dengan kejadian depresi pada remaja putri di Kota Yogyakarta. Tidak terdapat hubungan yang signifikan antara asupan zat besi dengan depresi. Namun, terdapat hubungan antara kebiasaan sarapan dan depresi pada remaja $(\mathrm{RP}=1,52 ; \mathrm{Cl}=1,071-2,162 ; p=<0,05)$. Kesimpulan. Kebiasaan sarapan pagi dapat dikaitkan dengan kejadian depresi pada remaja putri. Walaupun proporsi depresi remaja cukup tinggi dalam penelitian ini, namun hubungannya dengan anemia belum dapat dibuktikan secara signifikan.

Kata kunci: anemia, kebiasaan sarapan, depresi, remaja putri, aktivitas fisik

\section{PENDAHULUAN}

Masa remaja merupakan tahap krusial bagi pertumbuhan dan perkembangan manusia. Banyak tugas yang harus dicapai seorang remaja pada fase ini yang seringkali menjadi masalah bagi mereka dan mempengaruhi perkembangan psikisnya. ${ }^{1}$ Depresi merupakan masalah kesehatan mental yang sering terjadi pada remaja. National Institute of Mental Health (NIMH) menyatakan bahwa prevalensi depresi pada anak usia 9-17 tahun adalah 6 persen. ${ }^{2}$ Prevalensi masalah gangguan mental emosional di Indonesia untuk rentang usia 1524 tahun adalah sekitar 6 persen. ${ }^{3}$ Gangguan mental emosional pada kelompok usia 15-24 tahun di DIY sebesar 9,5 persen. World Health Organization (WHO) telah mengidentifikasi kesehatan mental sebagai masalah kesehatan remaja, yang diperkirakan akan menjadi isu kesehatan global pada tahun 2020. ${ }^{4}$ Gangguan neuropsikiatrik pada remaja merupakan pencetus beban penyakit dan kerugian karena kehilangan produktivitas sebesar 15-30 persen pada tiga tahun pertama dalam satu dekade kehidupan, ${ }^{5}$ meningkatkan risiko obesitas dan kejadian sindrom metabolik di usia dewasa, ${ }^{6,7}$ serta meningkatnya pemanfaatan pelayanan kesehatan dan gangguan kerja pada usia 20 tahun. ${ }^{8}$
Kerugian yang diakibatkan oleh depresi menjadi dasar banyak penelitian dalam mengkaji berbagai hal yang dapat menurunkan risiko depresi, diantaranya adalah pola makan dan aktivitas fisik. Beberapa penelitian melaporkan bahwa kesehatan mental dipengaruhi oleh kualitas makan dan kebiasaan sarapan. ${ }^{9,10}$ Zatzat gizi dalam makanan tampaknya memainkan peran penting dalam keseimbangan dopamin, serotonin, dan norepinefrin yang merupakan neurotransmiter paling berpengaruh dalam kontrol suasana hati dan perilaku seseorang. ${ }^{11,12}$ Peningkatan kadar serotonin dan dopamin serum ditemukan pada kelompok tikus yang diberi intervensi latihan fisik dibandingkan dengan kelompok kontrol, sehingga aktivitas fisik diketahui sebagai faktor protektif terjadinya depresi. ${ }^{13,14}$ Penelitian lain pada remaja putri dengan kondisi depresi ringan sampai sedang menunjukkan perbaikan simtom depresi setelah diintervensi oleh latihan fisik selama 8 minggu. ${ }^{15}$

Sintesis dopamin dan serotonin di otak dipengaruhi oleh tirosin hidroksilase dan triptofan hidroksilase dimana enzim ini sangat dipengaruhi oleh ketersediaan zat besi sebagai kofaktornya. ${ }^{16}$ Penelitian Shariatpanaahi et al, menyatakan bahwa ada hubungan antara depresi dengan penurunan kadar feritin sebelum terjadinya anemia. Pernyataan ini menimbulkan 
dugaan bahwa keadaan anemia akan meningkatkan kejadian depresi. ${ }^{17}$ Penelitian lain pada wanita anemia yang diberi suplementasi zat besi menunjukkan perbaikan skor depresi dan stres dibandingkan dengan wanita anemia yang diberi placebo. ${ }^{18}$

Prevalensi anemia remaja putri di DIY pada tahun 2012 sebesar 36 persen dan prevalensi di Kota Yogyakarta mencapai 35,2 persen. $^{19}$ Kerugian akibat anemia berkaitan dengan penurunan produktivitas kerja dan daya tahan, terganggunya perkembangan fisik dan psikis, peningkatan kesakitan, hingga kematian. Penelitian yang menghubungkan anemia dan depresi selama ini banyak dilakukan pada populasi lansia atau orang dengan penyakit tertentu yang secara fisiologis menyebabkan anemia dan depresi, sedangkan pada remaja anemia masih perlu penegasan korelasi yang mungkin terjadi di antara keduanya. Perbedaan usia, jenis kelamin, gaya hidup, dan penyakit tertentu diperkirakan memengaruhi perbedaan hasil penelitian. ${ }^{20}$

\section{METODE}

Penelitian ini menggunakan desain cross sectional, dengan subjek 250 orang siswi Sekolah Menengah Atas (SMA) dan Madrasah Aliyah (MA) di Kota Yogyakarta. Kota Yogyakarta dipilih secara purposive karena prevalensi anemia remaja putri yang cukup tinggi pada tahun 2012. Pemilihan subjek dilakukan secara stratified random sampling di 7 SMA di 4 kecamatan di Kota Yogyakarta. Keempat kecamatan tersebut merupakan kecamatan yang memiliki jumlah SMA paling banyak di Kota Yogyakarta. Besar sampel minimal penelitian ini adalah 234 orang. Jumlah subjek untuk masingmasing sekolah ditentukan secara proporsional dari jumlah seluruh siswi di sekolah terpilih.
Kadar hemoglobin diukur menggunakan Quick-Check Hb Hemoglobin System Depkes RI AKL No: 20205312473, yang memiliki range pengukuran $\mathrm{Hb}$ 4,5-25,6 g/dL, dengan presisi 0,26 persen sampai 1,7 persen coefficient of variation (CV). Data dikategorikan anemia jika nilai $<12 \mathrm{gr} / \mathrm{dL}$, dan tidak anemia jika nilai 12-16 gr/dL. Inventori Depresi Remaja (IDR) digunakan untuk mengukur tingkat depresi pada remaja, terdiri dari 34 item pernyataan dengan 4 skala Likert. Kategori depresi jika skor $>30$, dan tidak depresi jika skor $\leq 30$. Tingkat aktivitas diukur menggunakan International Physical Activity Questionaire (IPAQ) yang dinyatakan dengan MET-menit/minggu. Data dikategorikan menjadi aktivitas rendah jika skor $<600$ MET-menit/ minggu, sedang jika skor 600-2999 MET-menit/ minggu, dan aktivitas tinggi jika skor $\geq 3000$ MET-menit/minggu. Sedangkan data asupan zat besi menggunakan Semi Quantitative Food Frequency Questionnaire (SQ-FFQ). Asupan zat besi dikategorikan cukup jika asupan per hari $\geq 80$ persen AKG. Kebiasaan sarapan subjek diperoleh dengan wawancara, kemudian dikategorikan menjadi terbiasa sarapan jika sarapan $>3$ kali dalam satu minggu, dan tidak terbiasa sarapan jika $\leq 3$ kali dalam satu minggu. ${ }^{21}$

Uji chi square dilakukan untuk menilai hubungan antara anemia dan depresi menggunakan software Stata Intercooled versi 11.0. Penelitian ini merupakan bagian dari penelitian besar ${ }^{22}$ yang telah mendapat izin dan kelaikan etik dari Komite Etik Penelitian Kedokteran Kesehatan Universitas Gadjah Mada dengan nomor surat KE/FK/958/EC/2015.

\section{HASIL}

Subjek penelitian ini sebanyak 250 orang berusia 14-18 tahun. Sebagian besar subjek berstatus gizi normal dengan rata-sata Z-score 0,1 SD. Berdasarkan hasil pemeriksaan kadar 
hemoglobin, hanya sebanyak 4,4 persen responden masuk dalam kategori anemia (Tabel 1). Cukup banyak responden yang termasuk dalam kategori depresi, yaitu sebanyak 32,8 persen. Lebih dari setengah jumlah responden memiliki tingkat aktivitas fisik yang rendah atau kurang dari 600 METmenit/minggu $(60,8 \%)$. Berdasarkan hasil penilaian konsumsi makanan menggunakan Semi Quantitative FFQ, diketahui sebagian besar responden memiliki asupan zat besi yang kurang dari AKG (Tabel 1).

Tabel 1. Distribusi Frekuensi Karakteristik Subjek

\begin{tabular}{lcc}
\hline \multicolumn{1}{c}{ Variabel } & $\mathrm{n}$ & $\%$ \\
\hline $\begin{array}{l}\text { Status anemia } \\
\text { Anemia }\end{array}$ & 11 & 4,40 \\
$\quad$ Tidak anemia & 239 & 95,60 \\
Tingkat depresi & & \\
$\quad$ Depresi & 82 & 32,80 \\
$\quad$ Tidak depresi & 168 & 67,20 \\
Tingkat aktivitas fisik & & \\
$\quad$ Rendah (<600 MET-menit/minggu) & 152 & 60,80 \\
$\quad$ Sedang (600-2999 MET-menit/minggu) & 81 & 32,40 \\
$\quad$ Tinggi (>3000 MET-menit/minggu) & 17 & 6,80 \\
Kebiasaaan sarapan & & \\
$\quad$ Terbiasa sarapan & 176 & 70,40 \\
$\quad$ Tidak terbiasa & 74 & 29,60 \\
Konsumsi suplemen & & \\
$\quad$ Ya & & 14,80 \\
Tidak & 37 & 85,20 \\
Asupan zat besi & 213 & 96,80 \\
$\quad$ Cukup ( $\geq 80 \%$ AKG) & & \\
Tidak cukup (<80\% AKG) & & \\
\hline
\end{tabular}

Lebih dari setengah (54\%) subjek anemia mengalami depresi, namun hasil uji statistik menunjukkan bahwa tidak ada hubungan antara anemia dan depresi pada remaja puteri $(p>0,05)$. Pada penelitian cross-sectional, estimasi risiko relatif dinyatakan dengan ratio prevalence (PR). Rasio prevalens pada penelitian ini adalah 1,715 dengan nilai confidence interval range $(\mathrm{Cl} 95 \%)$ pada rentang 0,969-3,034
(Tabel 2). Interval kepercayaan menunjukkan rentang nilai rasio prevalens yang diperoleh pada populasi terjangkau apabila sampling dilakukan berulang-ulang. Interval kepercayaan yang tidak melewati angka 1 memberi makna bahwa pada penelitian ini variabel bebas tersebut (anemia) belum tentu merupakan faktor risiko terjadinya depresi pada remaja putri. 
Tabel 2. Hubungan Anemia dan Depresi

\begin{tabular}{|c|c|c|c|c|c|c|c|c|}
\hline \multirow{2}{*}{ Variabel } & \multicolumn{2}{|c|}{ Depresi } & \multicolumn{2}{|c|}{ Tidak depresi } & \multirow{2}{*}{$x^{2}$} & \multirow{2}{*}{$\mathrm{RP}$} & \multirow{2}{*}{$95 \% \mathrm{Cl}$} & \multirow{2}{*}{$p$} \\
\hline & $n$ & $\%$ & $n$ & $\%$ & & & & \\
\hline \multicolumn{9}{|l|}{ Status anemia } \\
\hline Anemia & 6 & 54,55 & 5 & 45,45 & 2,468 & 1,715 & $0,969-3,034$ & 0,185 \\
\hline Tidak anemia & 76 & 31,80 & 163 & 68,20 & & & & \\
\hline
\end{tabular}

Berdasarkan Tabel 3 diketahui bahwa tidak terdapat hubungan yang signifikan baik antara tingkat aktivitas fisik rendah $(p=0,798 ; \mathrm{Cl}=0,461$ $1,809)$ dan tingkat aktivitas sedang $(p=0,876$; $\mathrm{Cl}=0,462-1,927)$ terhadap depresi. Subjek yang mengalami depresi terdistribusi hampir sama berdasarkan varibel tingkat aktivitas fisik (rendah, sedang, tinggi), persentase tertinggi adalah subjek depresi dengan tingkat aktivitas tinggi yaitu sebesar 35,29 persen. Namun, hasil uji secara statistik tidak bermakna yang menunjukkan bahwa tidak ada hubungan antara aktivitas fisik dengan kejadian depresi pada subjek remaja putri (Tabel 3). Hal yang sama untuk variabel asupan zat besi, dalam penelitian ini tidak menunjukkan hubungan yang signifikan dengan depresi $(p>0,05)$. Terdapat hubungan antara kebiasaan sarapan pagi dengan kejadian depresi pada remaja putri, secara statistik bermakna $(p<0,05 ; \mathrm{Cl}=1,071-2,162)$. Sebanyak 71,6 persen subjek yang terbiasa sarapan, memiliki skor depresi yang rendah. Hampir setengah subjek $(43,3 \%)$ yang tidak terbiasa sarapan mengalami depresi.

Tabel 3. Hubungan Tingkat aktivitas Fisik, Kebiasaan Sarapan, dan Asupan Zat Besi dengan Depresi

\begin{tabular}{|c|c|c|c|c|c|c|c|c|}
\hline \multirow{2}{*}{ Variabel } & \multicolumn{2}{|c|}{ Depresi } & \multicolumn{2}{|c|}{ Tidak depresi } & \multirow{2}{*}{$x^{2}$} & \multirow{2}{*}{$\mathrm{RP}$} & \multirow{2}{*}{$95 \% \mathrm{Cl}$} & \multirow{2}{*}{$p$} \\
\hline & $\mathrm{n}$ & $\%$ & $\mathrm{n}$ & $\%$ & & & & \\
\hline \multicolumn{9}{|l|}{ Tingkat aktivitas fisik } \\
\hline Rendah & 49 & 32,24 & 103 & 67,76 & 0,08 & 0,913 & $0,461-1,809$ & 0,798 \\
\hline Sedang & 27 & 33,33 & 54 & 66,67 & 0,02 & 0,944 & $0,462-1,927$ & 0,876 \\
\hline Tinggi & 6 & 35,29 & 11 & 64,71 & & & & \\
\hline \multicolumn{9}{|l|}{ Kebiasaan sarapan } \\
\hline Tidak terbiasa & 32 & 43,24 & 42,56 & 56,76 & 5,20 & 1,52 & $1,071-2,162$ & $0,023^{*}$ \\
\hline Terbiasa & 50 & 28,41 & 126 & 71,59 & & & & \\
\hline \multicolumn{9}{|l|}{ Asupan Fe } \\
\hline Kurang & 78 & 32,23 & 164 & 67,77 & 1,109 & 0,644 & $0,314-1,319$ & 0,444 \\
\hline Cukup & 4 & 50,00 & 4 & 50,00 & & & & \\
\hline
\end{tabular}

Keterangan*: signifikan $(p<0,05)$ 


\section{PEMBAHASAN}

Remaja anemia ditemukan 4,4 persen dalam penelitian ini, lebih rendah dari angka anemia remaja pada tahun 2012 yang melaporkan 36 persen remaja putri anemia. ${ }^{19}$ Terdapat beberapa perubahan yang kemungkinan menurunkan angka anemia remaja di Kota Yogyakarta pada tahun 2012-2015 saat penelitian ini dilakukan, salah satunya adalah program suplementasi zat besi pada remaja putri yang mulai dilakukan sejak 2015 di beberapa sekolah di Kota Yogyakarta. Wisnusanti melaporkan prevalensi anemia pada siswa SMP berstatus gizi normal di Kota Yogyakarta sebesar 15,15 persen, ${ }^{20}$ sedangkan Destriyani pada tahun 2018 melaporkan prevalensi anemia remaja putri di Kota Yogyakarta sebesar 13,13 persen. ${ }^{21}$ Kedua laporan penelitian di kota yang sama menunjukkan prevalensi yang lebih rendah dari tahun 2012, metode pengambilan sampel darah yang dilakukan oleh Wisnusanti dan Destriyani berbeda dengan metode yang dilakukan dalam penelitian ini. Selain itu, lokasi kecamatan dalam penelitian ini dipilih dengan cara purposive sehingga memungkinkan terjadinya bias.

Depresi ditemukan pada 32,8 persen remaja putri yang terlibat dalam penelitian ini. Angka ini jauh lebih tinggi bila dibandingkan dengan laporan Riskesdas DI Yogyakarta sebesar 9,5 persen untuk kelompok usia 1524 tahun. Perbedaan prevalensi ini dapat terjadi karena perbedaan instrumen yang digunakan. Pada Riskesdas, gangguan mental emosional diukur menggunakan Self Reporting Questionnaire (SRQ) yang terdiri dari 20 butir pertanyaan, sedangkan dalam penelitian ini menggunakan Inventori Depresi Remaja (IDR) yang dikembangkan oleh Prawiroharjo untuk mengukur gangguan mental spesifik (depresi) dan mengacu pada siklus perkembangan tertentu, dalam hal ini fase remaja. Sebanyak 34 butir pertanyaan pada IDR lebih spesifik mengukur depresi pada remaja, dan menghindari kemungkinan undiagnosed depression yang mungkin terjadi jika mengunakan instrumen lain yang tidak spesifik untuk remaja. ${ }^{22,23}$ Studi di India oleh Bansal et al, melaporkan bahwa prevalensi remaja depresi sebesar 18,4 persen dengan menggunakan Beck's Depression Inventory (BDI). ${ }^{23}$ Angka lebih tinggi dilaporkan dalam penelitian Jha et al, bahwa di antara 1.412 siswa subjek penelitiannya, ditemukan 49,2 persen remaja yang depresi dan sebesar 7,7 persen termasuk dalam kategori depresi berat. Prevalensi keseluruhan depresi secara signifikan $(p<0,001)$ lebih tinggi di antara anak perempuan $(55,1 \%)$ dibandingkan anak laki-laki $(45,8 \%))^{24}$

Berdasarkan hasil uji bivariat, diketahui bahwa tidak ada hubungan yang signifikan antara anemia dan depresi. Jumlah subjek anemia yang kecil mungkin menjadi alasan tidak terbuktinya hipotesis dalam penelitian ini. Beberapa studi anemia pada subjek penderita penyakit tertentu, rendahnya kadar hemoglobin $(\mathrm{Hb})$ berhubungan dengan meningkatnya risiko depresi pada seseorang. Namun pada kondisi ini, depresi tidak hanya disebabkan oleh rendahnya zat besi yang berperan dalam regulasi dopamin dan serotonin dalam pengaturan mood, namun juga dipengaruhi oleh status kesehatan subjek. ${ }^{25}$

Penelitian sebelumnya dilakukan pada wanita dewasa usia subur usia $\geq 17$ tahun. ${ }^{28}$ Subjek dalam penelitian ini adalah remaja putri usia 14-18 tahun. Pada masa ini terjadi kondisi emosional yang fluktuatif dan sangat dipengaruhi 
oleh kondisi lingkungan dan kepribadian remaja tersebut dalam menyikapi permasalahan. Pada satu sisi, kondisi kesehatan remaja yang cenderung sehat meminimalkan bias depresi dan atau anemia yang disebabkan oleh penyakit tertentu. Namun keadaan emosional remaja sehat lebih dipengaruhi oleh faktor psikososial lain, dibandingkan dengan status anemia. Terlepas dari jumlah subjek anemia yang kecil pada penelitian ini, tampaknya persepsi remaja terhadap tingginya tuntutan sekolah, orang tua, dan teman berkontribusi dalam memengaruhi kondisi emosional remaja. ${ }^{29}$

Pengukuran status besi mengunakan parameter hemoglobin saja mungkin tidak cukup untuk membuktikan keterkaitan antara anemia dan depresi. Keadaan emosi seseorang dapat sangat fluktuatif, sedangkan perubahan kadar $\mathrm{Hb}$ membutuhkan waktu lama untuk berubah, sesuai dengan usia eritrosit dalam tubuh $( \pm 120$ hari). Penurunan kadar $\mathrm{Hb}$ hingga di bawah normal merupakan tahap akhir defisiensi besi setelah melewati tahap deplesi cadangan besi dalam bentuk feritin di hati. ${ }^{30}$ Feritin mengalami penurunan paling awal saat terjadi kekurangan zat besi. Pengukuran status besi menggunakan serum feritin memiliki kelemahan, yaitu kadarnya yang sangat dipengaruhi oleh fase akut. Kadar feritin akan meningkat sebagai respon terhadap inflamasi, ${ }^{31}$ sehingga perlu pemeriksaan penunjang biomarkers inflamasi seperti C-reactive protein (CRP) atau Alpha1-acid glycoprotein (AGP) untuk memastikan bahwa tingginya kadar feritin bukan merupakan respon inflamasi yang sedang terjadi pada saat pengukuran dilakukan. ${ }^{32}$

Shariatpanaahi et al, mengemukakan bahwa penurunan kadar feritin serum akan meningkatkan risiko depresi pada wanita muda. ${ }^{17}$ Hasil ini tidak sejalan dengan penelitian Armony-Sivan et al, dan Richardson et al, yang melaporkan tidak ada hubungan status besi ( $\mathrm{Hb}, \mathrm{MCV}, \mathrm{ZPP}$, sTfR, dan serum feritin) dengan simptom depresi pada wanita. ${ }^{28} \mathrm{Vitamin}$ dan mineral yang terkandung dalam makanan bermanfaat sebagai kofaktor reaksi-reaksi kimiawi dalam tubuh, termasuk otak dalam regulasi mood. ${ }^{33}$ Namun, hasil uji bivariat tidak menunjukkan hubungan yang signifikan antara asupan zat besi dengan depresi pada remaja. Mora mengatakan bahwa kecukupan asupan gizi saja belum cukup menjelaskan peran zat gizi sebagai pencegahan dan atau penanganan depresi. ${ }^{34}$ Selain itu, kemungkinan terjadi missreporting atau underreporting asupan dapat menjadi alasan tidak tercapainya tujuan dari penilaian asupan zat gizi.

Sarapan dan aktivitas fisik merupakan bagian dari perilaku pola hidup sehat yang bermanfaat untuk kesehatan, baik secara fisik maupun mental. ${ }^{36}$ Dalam penelitian ini, terdapat hubungan yang signifikan antara kebiasaan sarapan dan depresi pada remaja putri. Remaja putri yang tidak terbiasa sarapan pagi lebih banyak depresi dibandingkan dengan remaja yang terbiasa sarapan pagi. Hasil ini mendukung penelitian O'Sullivan et al, yang menyatakan bahwa sarapan merupakan faktor penting dalam hubungan lifestyle dan kesehatan mental pada remaja. ${ }^{9}$ Kebiasaan sarapan pagi berhubungan dengan meningkatnya status kesehatan mental. Studi pada remaja di Iran melaporkan bahwa komposisi berbagai makanan yang dikonsumsi saat sarapan terdiri atas zat gizi makro dan mikro yang memberikan manfaat untuk kesehatan mental. ${ }^{37}$ Makanan sumber karbohidrat sebagai 
zat gizi makro utama, berperan penting untuk sintesis tryptophan. Asam amino ini merupakan prekursor pembentuk serotonin yang terlibat dalam pengaturan mood. ${ }^{38}$ Tetapi faktor lain yang tidak kalah penting dalam hal ini adalah kualitas sarapan itu sendiri. Oddy et al, melaporkan bahwa skor depresi pada remaja berhubungan dengan pola makan western yang cenderung tinggi lemak dan rendah serat, sedangkan perbaikan skor depresi berhubungan dengan tingginya asupan sayur-sayuran hijau dan buah segar (pola makan sehat). ${ }^{39}$ Beberapa penelitian menunjukkan bahwa asupan asam lemak esensial dan mikronutrien lainnya dapat mencegah gangguan kesehatan mental. ${ }^{40-42}$

Pola makan seimbang dan melakukan aktivitas fisik teratur merupakan kunci mempertahankan berat badan ideal. Lebih dari itu, aktivitas fisik juga memberikan manfaat dalam menjaga kesehatan mental. Namun hubungan tingkat aktivitas fisik dan depresi tidak terbukti secara statistik dalam penelitian ini. Hal ini bertentangan dengan beberapa penelitian sebelumnya yang menyebutkan bahwa aktivitas fisik merupakan faktor penting untuk mengurangi depresi. ${ }^{13-15}$ Penelitian kohort oleh Toseeb et al, melaporkan hasil yang serupa, bahwa pada populasi remaja yang menjadi subjek penelitiannya, gejala depresi tidak signifikan diprediksi oleh aktivitas fisik. ${ }^{43}$ Sedangkan Sagatun et al, mengemukakan bahwa tingkat aktivitas fisik hanya sedikit memengaruhi kesehatan mental pada remaja. ${ }^{44}$

Dalam penelitian ini, beberapa subjek dengan tingkat aktivitas tinggi memiliki skor depresi yang tinggi. Kondisi ini mengindikasikan bahwa ada hal lain yang memengaruhi hubungan tingkat aktivitas fisik dengan terjadinya depresi. Menurut
Ten Hope, motivasi seseorang dalam melakukan aktivitas fisik memengaruhi hasil yang didapatkan dari aktivitas tersebut. ${ }^{45}$ Aktivitas fisik yang dilakukan orang dewasa memiliki tujuan tertentu, seperti untuk kesehatan, mendapatkan bentuk tubuh ideal, sebagai sarana bersosialisasi, atau untuk sekedar bersenang-senang. Sedangkan pada remaja, yang juga seorang pelajar, aktivitas fisik yang dijalani belum tentu disertai oleh motif yang berasal dari dalam dirinya sendiri. Kegiatan ekstrakurikuler di luar sekolah, tambahan les pelajaran, seringkali menjadi beban tersendiri bagi remaja, sehingga remaja tidak bahagia melakukannya. ${ }^{29}$ Pada penelitian ini, walaupun hasil recall aktivitas menghasilkan skor tinggi, namun jika motif remaja melakukan aktivitas tersebut hanya untuk memenuhi kewajiban saja, maka manfaat aktivitas fisik terhadap tingkat depresi tidak tercapai. Lippke et al, menyampaikan hal yang sama, bahwa pada remaja dengan tingkat aktivitas tinggi dan memiliki tingkat stres tinggi, mereka memiliki motivasi yang rendah untuk melakukan aktivitas tersebut. ${ }^{46}$ Memiliki tujuan dalam melakukan aktivitas fisik merupakan faktor penting, namun menikmati proses dalam mencapai tujuan tersebut juga sama pentingnya. ${ }^{45}$

\section{KESIMPULAN}

Kebiasaan sarapan pagi dapat dikaitkan dengan kejadian depresi pada remaja putri di Kota Yogyakarta. Sebagian besar remaja putri memiliki tingkat aktivitas fisik yang rendah, namun belum bisa dikaitkan dengan kejadian depresi pada remaja putri. Walaupun proporsi depresi remaja cukup tinggi dalam penelitian ini, hubungannya dengan anemia belum dapat dibuktikan secara signifikan. 


\section{SARAN}

Diperlukan upaya kerjasama antara pihak sekolah dan petugas kesehatan dalam mempromosikan pentingnya kesehatan mental. Untuk penelitian selanjutnya, hendaknya dilakukan pemeriksaan anemia dengan tidak hanya menggunakan parameter $\mathrm{Hb}$, tetapi juga menggunakan feritin sebagai paramater simpanan besi dalam tubuh.

\section{UCAPAN TERIMA KASIH}

Ucapan terima kasih disampaikan kepada Lembaga Pengelola Dana Pendidikan (LPDP) yang telah berkontribusi dalam memberi bantuan dana beasiswa untuk penelitian ini.

\section{DAFTAR PUSTAKA}

1. Raphael B. Promoting the Mental Health and Wellbeing of Children and Young People. Discussion Paper: Key Principles and Directions. Canberra: Department of Health and Aged Care; 2000.

2. NIMH. Major Depression among Adolescents. Diunduh dari: http://www.nimh. nih.gov/health/statistics/prevalence/majordepression-among adolescents.shtml, tanggal 12 Januari 2015.

3. Badan Penelitian dan Pengembangan Kesehatan, Kementerian Kesehatan RI. Riset Kesehatan Dasar (Riskesdas) 2013. Jakarta: Kementerian Kesehatan; 2013.

4. World Health Organization. Nutrition in Adolescence-Issues and Challenges for Health Sector: Issues in Adolescent Health and Development. Geneva: World Health Organization; 2005.
5. LopezAD. Disease Control Priorities Project. Global Burden of Disease and Risk Factors. New York: Oxford University Press; 2006.

6. Vanhala M, Jokelainen J, KeinanenKiukaanniemi S, Kumpusalo E, Koponen H. Depressive Symptoms Predispose Females to Metabolic Syndrome: A 7-Year Follow-Up Study. Acta Psychiatr Scand. 2009;119(2):137-42.

7. Yu ZM, Parker L, Dummer TJ. Depressive Symptom, Diet Quality, Physical Activity, and Body Composition among Population in Nova Scotia, Canada: Report from Partnership for Tomorrow's Health. Preventive Medicine. 2014;61:106 -13.

8. Keenan-Miller DMA, Hammen CL, Brennan PA. Health Outcomes Related to Early Adolescent Depression. Journal of Adolescent Health. 2007;41(3):256-62.

9. O'SullivanTA, Robinson M, Kendall GE, Miller M, Jacoby $\mathrm{P}$, Silburn SR, et al. $A$ Good-quality Breakfast is Associated with Better Mental Health in Adolescence. Public Health Nutrition. 2008;12(2):249-58.

10. Fulkerson JA, Sherwood NE, Perry CL, Neumark-Sztainer D, Story M. Depressive Symptoms and Adolescent Eating and Health Behaviors: A Multi-Facet View in a Population-Based Sample. Preventive Medicine. 2004;38(6):865-75.

11. Jacobs BL. Depression: The Brain Finally Gets into The Act. American Psycological Society. 2004;13(3):103-6.

12. Dunne A. Effect of Food on Emotional Wellbeing and Mental Health. Nursing and Residential Care. 2010;12(4):165-8. 
13. Lopresti AL, Hood SD, Drummond PD. A Review of Lifestyle Factors that Contribute to Important Pathways Associated with Major Depression: Diet, Sleep, and Exercise. Journal of Affective Dissorder. 2013;148(1):12-27.

14. Adeniyi AF, Okafor NC, Adeniyi CY. Depression and Physical Activity in a Sample of Nigerian Adolescents: Levels, Relationships, and Predictors. Child and Adolescent Psychiatry and Mental Health. 2011;5(16):1-10.

15. Gerber M, Kalak N, LemolaS, Clogh PJ, Puhse U, Elliot C, et al. Adolescents Exercise and Physical Activity are Associated with Mental Toughness. Mental Health and Physical Activity. 2012;5(1):35-42.

16. Kim J, Wessling-Resnick M. Iron Mechanism of Emotional Behavior. Journal of Nutritional Biochemistry. 2014;25(11):1101-7.

17. Shariatpanaahi MV, Shariatpanaahi ZV, Moshtaaghi M, Shahbaazi SH, Abadi A. The Relationship between Depression and Serum Ferritin Level. European Journal of Clinical Nutrition. 2007; 61(4):532-5.

18. Beard JL, Hendricks MK, Perez EM, MurrayKolb LE, Berg A, Vernon-Feagans L, et al. Maternal Iron Deficiency Anemia Affects Postpartum Emotion and Cognition. The Journal of Nutrition. 2005;135(2):267-72.

19. Dinkes Prov DIY. Laporan Akhir Screening Anemia pada Remaja di Provindi DIY tahun 2012. Yogyakarta: Dinas Kesehatan Provinsi DIY; 2012.

20. Wisnusanti SU. Hubungan Obesitas, Kadar Feritin dan Kadar Hepcidin dengan Kejadian Anemia pada Remaja di Sekolah Menengah
Pertama (SMP) Kota Yogyakarta. Tesis. Yogyakarta: Program Pasca Sarjana IImu Kesehatan Masyarakat Universitas Gadjah Mada, 2017.

21. Destriyani. Hubungan Status Gizi, Asupan Zat Gizi Makro, dan Mikro dengan Kejadian Anemia pada Remaja Putri di Kota Yogyakarta. Tesis. Yogyakarta: Program Pasca Sarjana IImu Kesehatan Masyarakat Universitas Gadjah Mada, 2018.

22. Prawirohardjo RS. Depresi pada Remaja Pelajar di Kotamadya Yogyakarta, Penyusunan Inventori Baru, Penentuan Prevalensi dan Faktor-Faktor yang Berpengaruh pada Depresi Serta Terapinya. Disertasi. Yogyakarta: Program Doktor IImu Psikologi Universitas Gadjah Mada, 1989.

23. Bansal V, Goyal S, Srivastava K. Study of Prevalence of Depression in Adolescent Students of a Public School. Ind Psychiatry J. 2009;18(1): 43-6.

24. Jha KK, Singh SK, Nirala SK, Kumar C, Kumar P, Aggrawal N. Prevalence of Depression among School-going Adolescents in an Urban Area of Bihar, India. Indian J Psychol Med. 2017;39(3):287-92.

25. Milligen BA, Vogelzangs $\mathrm{N}$, Smit $\mathrm{JH}$, Penninx BW. Hemoglobin Levels in Persons with Depressive and/or Anxiety Disorders. Journal of Psychosomatic Research. 2014;76(4):317-21.

26. Dewi AN, Mulyati T. Hubungan Kebiasaan Sarapan Dengan Kadar Hemoglobin Pada Remaja Putri (Studi Penelitian di SMP Negeri 13 Semarang). Journal of Nutrition College. 2014;3(4): 824-30. 
27. Hermanto RA. Hubungan Anemia dan Depresi pada Remaja Putri di Kota Yogyakarta. Tesis. Yogyakarta: Program Pasca Sarjana IImu Kesehatan Masyarakat Universitas Gadjah Mada, 2016.

28. Armony-Sivan R, Shao J, Li M, Zhao G, Zhao $Z, X u G$, et al. No Relationship between Maternal Iron Status and Postpartum Depression in Two Samles in China. Journal of Pregnancy. 2012:521431.

29. Moksnes UK, Lillefjell M, Espnes GA. The Relationship between Stress, Leisure Time Vigorous Physical Activity and Depressive Symptom in Adolescents. J Child Adolesc Behav. 2013;2(1):1-7.

30. Kasdan TS. Medical Nutrition Therapy for Anemia. In Mahan KL, Stump SE, editors. Krause's Food and Nutrition Theraphy. $11^{\text {th }}$ ed. Philadelphia: W.B Saunders; 2004. p. 810.

31. Kasdan TS. Nutritional Care in Anemia. In: Mahan LK, Stump SE, editors. Krause's Food, Nutrition and Diet Therapy. $9^{\text {th }}$ ed. Philadelphia: W.B Saunders; 1996.

32. Richardson AC, Heath AL, Haszard JJ, Polak MA, Houghton LA, Conner TS. Higher Body Iron is Associated with Greater Symptoms among Young Men but not Women: Observational Data from The Daily Life Study. Nutrients. 2015;7(8):6055-72.

33. Slavin JL, Lloyd B. Health Benefits of Fruits and Vegetables. Adv Nutr. 2012;3(4):50616.

34. Katherine M. Diet and Depression: $A$ Secondary Analysis from NHANES 19992002. Dissertasion. Tucson: Fepartment of
Nutritional Science University of Arizona, 2006.

35. Kim TH, Choi JY, Lee HH, Park Y. Association between Dietary Pattern in Depression in Korean Adolescent Girls. J Pediatr Adolesc Gynecol. 2015;28(6):533-37.

36. Kemenkes. Peraturan Menteri Kesehatan Republik Indonesia Nomor 41 Tahun 2014 Tentang Pedoman Gizi Seimbang. Jakarta: Kementerian Kesehatan Republik Indonesia; 2014.

37. Ahadi Z, Kelishadi R, Qorbani M, Zahedi H, Aram M, Motlagh ME, et al. Association of Breakfast Intake with Psychiatric Distress and Violent Behaviors in Iranian Children and Adolescent: the CASPIAN-IV Study. Indian J Pediatr. 2016;83(9):922-9.

38. Young SN, Regoli M, Leyton M, Pihl RO, Benkelfat $\mathrm{C}$. The Effect of Acute Tryptophan Depletion on Mood and Impulsivity in Polydrug Ecstasy Users. Psychopharmacology. 2014; 231:707-16.

39. Oddy $\mathrm{WH}$, Robinson $\mathrm{M}$, Ambrosini $\mathrm{GL}$, O'Sullivan TA, de Klerk NH, Beilin LJ, et al. The Association between Dietary Pattern and Mental Health in Early Adolescence. Preventive Medicine. 2009; 49(1):39-44.

40. Long SJ, Benton D. Effect of Vitamin and Mineral Supplementation on Stress, Mild Psychiatric Symptom and Mood in Nonclinical Samples: a Meta Analysis. Psychosomatic Medicine. 2013;75(2):14453.

41. Tahmasebi K, Amani R, Nazari Z, Ahmadi K, Moazzen S, Mostafavi SA. Association of Mood Dissorder with Serum Zinc Concentration in Adolescent Female 
Student. Biological Trace Element Research. 2017;178(2):180-8.

42. Veasy RC, Haskel-Ramsay CS, Kennedy DO, Tiplady B, Stevenson EJ. The Effect of Breakfast Prior to Morning Exercise on Cognitive Performance, Mood, and Appetite Later in the Day in Habitually Active Women. Nutrients. 2015;7(7):5712-32.

43. Toseeb U, Brage S, Corder K, Dunn VJ, Jones PB, Owens $M$, et al. Exercise and Depressive Symptoms in Adolescents, a Longitudinal Cohort Study. JAMA Pediatr. 2014;168(12):1093-100.

44. Sagatun A, Sogaard AJ, Bjertness E, Selmer
R, Heyerdahl S. The Association Between Weekly Hours of Physical Activity and Mental Health: A Three Year Follow-Up Study of 1516 Year Old Students in The City of Oslo, Nonway. BMC Public Health. 2007;7(155): 1-9.

45. Ten Hope MI. Physical Activity, Motivation, and Depression in College Students. Thesis. Redlands: University of Redlands Psychology Department, 2015.

46. Lippke S, Wienert J, Kuhlmann T, Fink S, Hambrecht R. Perceived Stress, Physical Activity, and Motivation: Findings from an Internet Study. Ann Sports Med Res. 2015;2(1):1012. 